\title{
The Optimum PV System Design to Meet Energy Requirements for a House and a Car in Conditions of Istanbul
}

\author{
Necati Aksoy ${ }^{1}$, Ipek Atik ${ }^{2}$, Ömer Faruk Farsakoğlu ${ }^{3}$, Saban Yilmaz ${ }^{4}$ \\ Dept of Electrical Electronics Engg, Faculty of Engineering Architecture, Kilis 7 Aralik University, Kilis, Turkey 1,2,3,4
}

\begin{abstract}
Nowadays, the demand of using renewable energy sources increases due to the rising of energy requirement for everyday life. Among renewable energy sources trends, power generation with PV Systems is one of the most demanding. These solar systems provide clean and sustainable energy. In terms of PV systems, grid-connected systems are more advantageous and useful. In that type PV System, the required energy, firstly, is supplied from battery and secondly, from electric grid in case of lack of solar energy to meet. In the article, it is done the optimum sizing with $\mathrm{Pv}$ Sol demo software in order to deal with the energy requirement for houses and cars of average family under climate conditions of the city of Istanbul. The designed system is connected to grid and it is just for meeting the energy need of average family's house and electric car. The PV generator produces $2996 \mathrm{kWh}$ energy annually. The energy requirement for electric car is $3009 \mathrm{kWh}$. The system works in performance of 81.6 percent annually.
\end{abstract}

Keywords: Renewable Energy, Solar Energy, Tesla, optimal PV system.

\section{INTRODUCTION}

Today, the interest of using renewable energy sources rises steadily in the energy market due to the increase of need of energy sources day by day. In last years, specifically, solar power energy producing systems are in demand. The photovoltaic systems which are able to produce electric energy directly from the radiation of sun and set up on almost every surface has low cost installment trait and increasing productivity. The systems are also easy to set up and environmentally friendly. Furthermore, it can be said that the PV systems connected to the grid is more favorable. The reason is that the energy demand can be compensated from firstly battery and secondly from electric grid in the situation that the systems has not gathering any solar power. It could be needed too much batter power if the system was not connected to the grid. For optimal planning, solar power is determined as primary source and the battery could be selected as secondary source, and lastly electric grid could be used [13]. The popularity of using electric cars riseseveryday in high-tech countries. It is obvious that electric cars are going to dominate future technological predictions. In addition to electric cars are environment friendly, they lead to \%65 energy savings. Moreover, electric cars use basic based electric motors. And, on the contrary to internal combustion engines, the motors contain less moving parts and components such as oil circulation, oxygen intake, pistons, belts, filters, sparking plugs etc. As a result, without having these parts the system acquires more flexibility and easy implementation [4-8].

Photovoltaic systems which have electric grid connection works based on the principle of consuming the produced electric directly instead of accumulating in batteries. The prospective energy requirement should be estimated accurately in the process of drawing project outlines. PV modules produce electrical energy as DC form when photons coming from atmosphere touch down semiconductor based surfaces. As next step, the produced energy feed the central electric grid using new generation inverters which could connect directly to central grid. With this process, produced energy on solar panels flows to energy grid instantly and directly. If the field and irradiance conditions are suitable, it is possible to produce electrical energy in the amount of how much it is demanded [9-12].

In the article, it is done optimum measurement estimation with using software called $\mathrm{Pv}$ Sol with considering Istanbul's climate conditions in order to supply enough energy to match house and electric car's energy need of average size families. All energy requirements for a electric car as well as an house could be provided with the systems which is connected to the grid. The unneedful produced energy could feed to the energy grid and could attain needed energy from the grid under the favor of twodirectional current meter [13].

\section{GRID-CONNECTED PV SYSTEMS}

Istanbul is among the cities which Electric Cars are being used. Due to the fact that, Istanbul (Latitude: 40o 58' 1', Longitude: $28 \mathrm{o} 49^{\prime} 1^{\prime \prime}$ ') is selected as the climate condition and trait. The irradiance map of Istanbul can be seen in Fig. 1. Annual total amount of irradiance is $1365 \mathrm{kWh} / \mathrm{m} 2$ and average temperature is $15,3 \mathrm{oC}$ under Istanbul's environment conditions. 
Vol. 5, Issue 12, December 2016

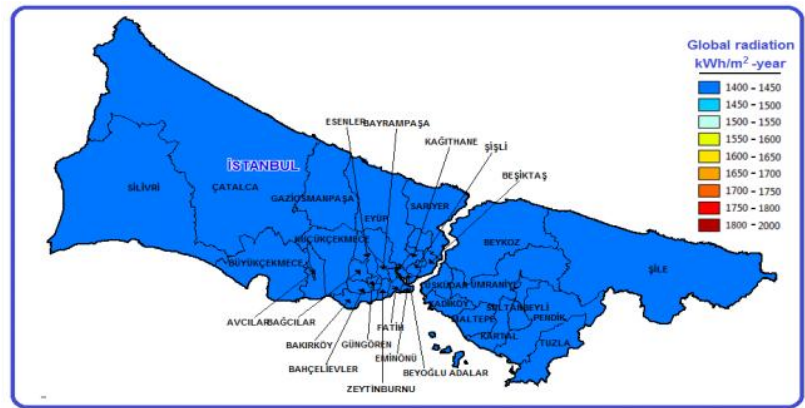

Fig. 1 The irradiance map of Istanbul

Although the value of irradiance amount is low in terms of Turkey's standards, it is way above of Europe's averages. The irradiance and temperature ratios could be seen Fig. 2.
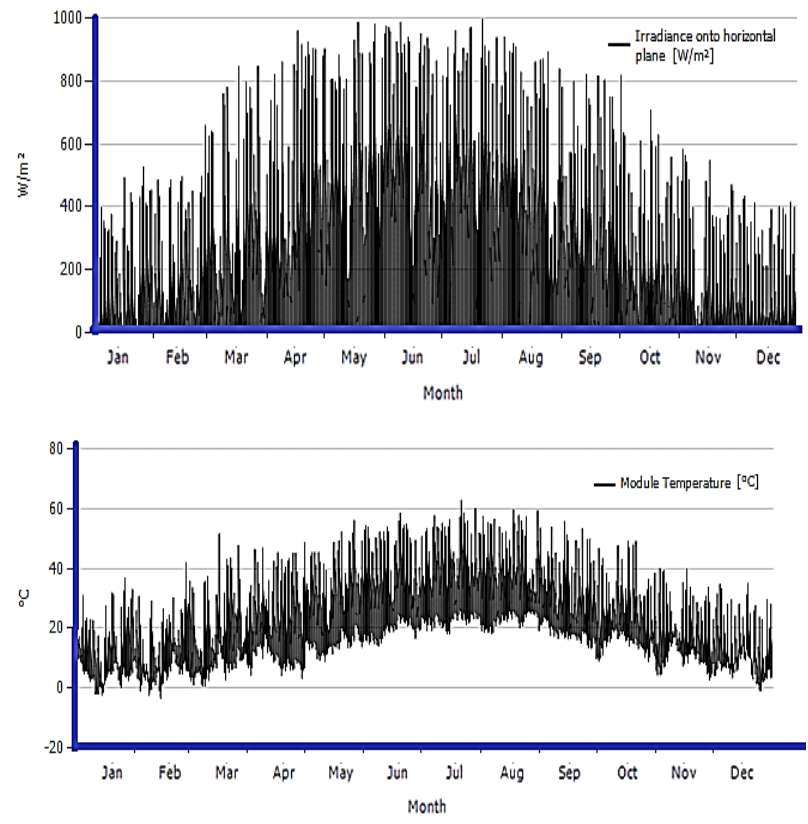

Fig. 2. Average Irradiance and Temperature Values for City of Istanbul

In grid-connected PV Systems, 250 W Si Polycrystalline photovoltaic panels which are made by Solarturk corp. are examined and totally around $2.5 \mathrm{kWppower}$ from panels are planned with 10 planes. Moreover, a PV panel is comprised of 60 cells which are connected serially and its width is $1001 \mathrm{~mm}$, height is $1665 \mathrm{~mm}$, and weight is 19 $\mathrm{kg}$. Furthermore, MPP voltage of the panel is $31.28 \mathrm{~V}$ and the panel's voltage without any load is $37.66 \mathrm{~V}$ and besides, MPP current is $8.01 \mathrm{~A}$ and short-circuit current is 8.66 A. Lastly, the total area that the panel covers is 16.7 square meter. The inverter that used in the system is Sunny Boy 2.5 and it's Nominal DC voltage is $360 \mathrm{~V}$, Maximum initial voltage is $600 \mathrm{~V}$, Maximum initial current is $10 \mathrm{~A}$, Nominal AC power is $2.5 \mathrm{~W}$. Therefore, serial-connected 10 Solarturk panel modules are sufficient for $250 \mathrm{~W}$ panel system. In addition, It has been designed an system which are enough around the energy demand of an average size family. Besides, annual energy requirement for an house is calculated by $4308 \mathrm{kWh}$.
Tesla Model S P90D model electric car which have $90 \mathrm{kWh}$ energy capacity has been selected. Moreover, every electric car manufactured by Tesla Motors is 100 percent electrical and could be called "pure electric car". Furthermore, Tesla P90D has totally $762 \mathrm{hp}$ engines (259hp front motors and 503 rear motors), it can reach 0 to $100 \mathrm{kmh}$ within 2.9 seconds. In addition, the car has all - wheel drive feature and once it's batteries are all charged, it can reach around $431 \mathrm{~km}$ range. The solar system which is planned for an house and electric car could be seen in Fig. 3.

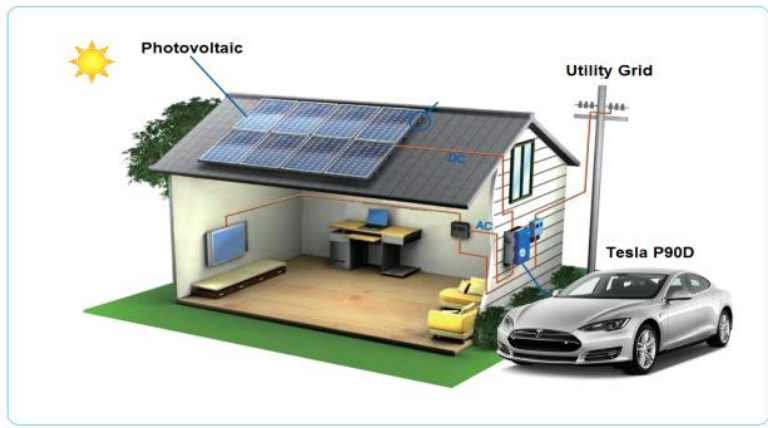

Fig. 3. The Planned Solar System for a House and an Electric Car

\section{III.OUTCOMES}

In simulation process, the energy requirement for an house and electric car in area of Istanbul has been met with using the product of Solarturk Energy called STR P 250, $250 \mathrm{~W}$ photovoltaic panels and Sunny Boy's 2.5 inverters. Recommended systems is a grid-connected system and is on direction to supply sufficient amount of energy for average size family without any restriction of their life standards. For that purpose, the system has been reached 81.6 percent performance merit and the PV generator has produced $2996 \mathrm{kWh}$ energy annually. Whereas $506 \mathrm{kWh}$ of provided energy has been directly used for house's energy demand as annually, $1224 \mathrm{kWh}$ of the total annual produced energy has been spent to charge the prospective electric car. In addition to that, redundant produced energy has been transmitted to electric distribution grid. On the other hand, annually $3009 \mathrm{kWh}$ energy at total has been needed for the energy requirement of prospective electric car. And to supply this amount of energy, $1224 \mathrm{kWh}$ of total needed energy has been provided directly from the solar system and the rest of total energy requirement of the car, which is amount of $1784 \mathrm{kWh}$, has been delivered from electric distribution grid. Besides, it has been reach $1792 \mathrm{~kg} \mathrm{CO} 2$ emission annually. Furthermore, the PV generator produced at most amount of energy that is around $360 \mathrm{kWh}$ in July and, on the contrary, at least amount of energy which is also around $135 \mathrm{kWh}$ in January. Farther, annual energy fluctuations could be seen in Fig. 4. As could be noticed, the energy demand from the grid is relatively less in summer time rather than other time due to the fact that energy generation in that time is far more using PV system. 
Vol. 5, Issue 12, December 2016

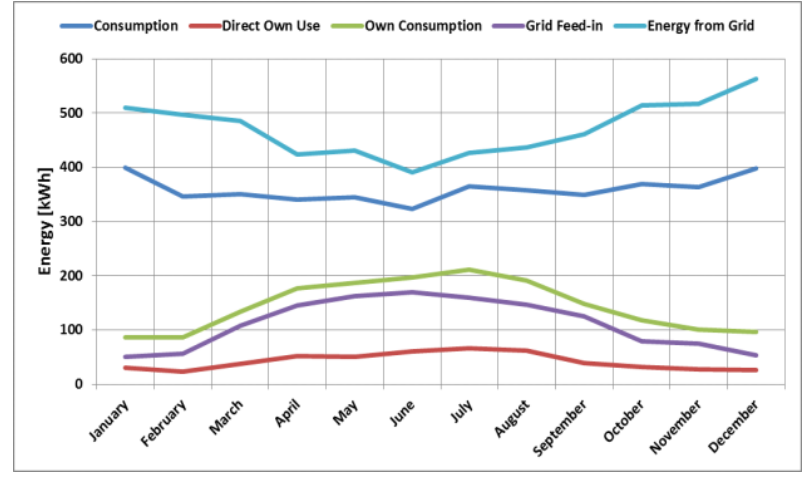

Fig 4. Annual Energy Fluctuations

The average system performance is around 81.6 percent but the performance reduces in summer time because of high temperature average. Associated with developing and progressive technology, renewable energy sources have been becoming more attractive method to meet energy requirements. More specifically, it can be clearly claim that the energy need of a house as well as an electric car could be provided with solar powered resources. In this direction, the proposed system is not only environmental friendly but also independent in terms of energy. The system's performance fluctuations can be seen in Fig. 5.

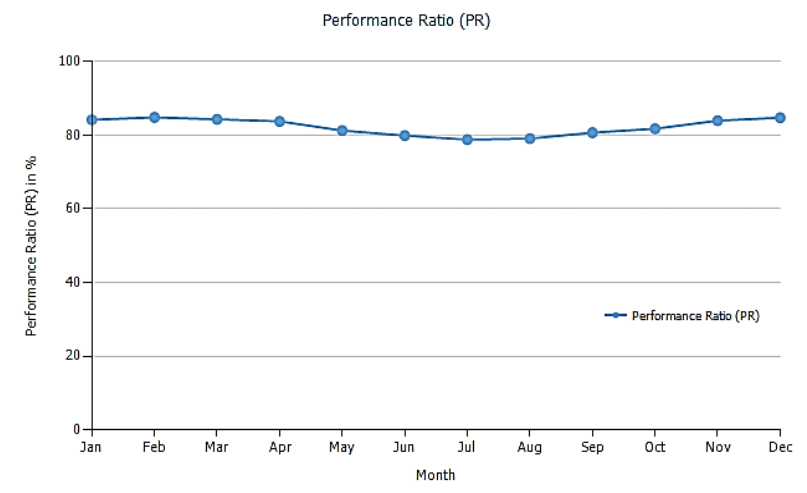

Fig 5. Performance Fluctuations

\section{IV.CONCLUSIONS}

First of all, it could be claimed that the main result of the study among several outcomes is that the energy requirement for a house and an electric car in area of the city of Istanbul has been provided in an optimum method. Furthermore, the system's main objective is supplying sufficient amount of energy for average-size family without any restriction of their lifestyle conditions. The performed PV panel have produced $2996 \mathrm{kWh}$ energy annually. Besides, $3009 \mathrm{kWh}$ energy has been required for proposed electric car. In addition, it has been reach the quantity of $1792 \mathrm{~kg} \mathrm{CO} 2$ emission. Moreover, the system has worked at average 81.6 percent performance merit. The significant proportion of dwelling energy consumption and transportation energy demand which are the most considerable segments of total energy demand of the world could be provided with using renewable energy sources. In that direction, the proposed system which is environmentally friendly could ensure the independency from the electric grid.

\section{REFERENCES}

[1] Kumbasar A., Da çeviricitemelli fotovoltaikele ktrikü retimsistemlerininincelenmesivesimülasyonu, Yüksek LisansTezi, Yıldız Teknik Üniversitesi, (2010).

[2] SabanYılmaz, ErdalKılıç, HasanRızaÖzçalık,’'Istanbul Sartlarında ÇalışanFotovoltaik Jeneratörün Performans Analizi”, Sürdürüle bilir Enerji Sempozyumu, II. Ankara Üniversitesi Çevre Günleri, 05 Haziran 2014, Ankara

[3] Özdemir Ş., Fotovoltaiksist emleriçinmi krodenetleyicili en yüksekgü çnoktasınıizley enbirkonvertörünger çekleştirilmesi, Yüksek Lisans Tezi, Gazi Üniversitesi,(2007).

[4] Şahin M. E., Okumuş H. İ., Güne şpili modülünün matlab/ simulin k xile modellenmesivesimülasyonu, Cilt 3, Say1 5, Haziran (2013) 17-25.

[5] Chenni, R., Makhlouf, M., Kerbache, T., and Bouzid, A,A detailed modeling method for photovoltaic cells, Elsevier, 32., (2007), 1724-1730.

[6] Çekinir S., Fotovoltaik güçsistemlerinin modelle nmesivebenzetimi YüksekLisansTezi, EgeÜniversitesi Fen Bilimleri Enstitüsü (2012).

[7] www.tesla.com/models, (accessed September 25, 2016)

[8] http://teslaturk.com/elektrikli-otomobil-mevcut-gelecek/ (accessed September 25, 2016)

[9] Raugei, M.; Frankl, P. Life cycle impacts and costs of photovoltaic systems: Current state of the art and future outlooks. Energy 2009, 34, 392-399.

[10] Zhai, P.; Williams, E.D. Dynamic hybrid life cycle assessment of energy and carbon of multicrystalline silicon photovoltaic systems. Environ. Sci. Technol. 2010, 44, 7950-7955.

[11] Nishimura, A.; Hayashi, Y.; Tanaka, K.; Hirota, M.; Kato, S.; Ito, M.; Araki, K.; Hu, E.J. Life cycle assessment and evaluation of energy payback time on high-concentration photovoltaic power generation system. Appl. energy 2010, 87, 2797-2807.

[12] Laleman, R.; Albrecht, J.; Dewulf, J. Life Cycle Analysis to estimate the environmental impact of residential photovoltaic systems in regions with a low solar irradiation. Renew. Sustain. Energy Rev. 2011, 15, 267-281.

[13] http://www.valentin-software.com/en/products/photovoltaics/57/ pvsol-premium (accessed September 25, 2016)

\section{BIOGRAPHY}

Necati Aksoy, graduated from Temple University in Philadelphia, had got his M.S. fromInstitute of Natural \& Applied Sciences in 2015, research assistant in Kilis 7 Aralik University, Department of Electrical Electronics Engineering, since 2016.

Ípek Atik, graduated from Gaziantep University in Turkey had got her Ph.D. fromInstitute of Natural \& Applied Sciences in 2016, researchassistant in Kilis 7 Aralik University, Department of Electrical Electronics Engineering, since September 2011.

Omer Faruk Farsakoğlu, graduated from Ankara University in Turkey had got his Ph.D. from Institute of Natural \& Applied Sciences in 1992, Prof. Dr. in Kilis 7 Aralik University, Department of Electrical Electronics Engineering, since 2011.

Şaban Yilmaz, graduated from Kahramanmaraş University in Turkey had got his Ph.D. from Institute of Natural \& Applied Sciences in 2015, Assist. Prof. in Kilis 7 Aralik University, Department of Electrical Electronics Engineering, since 2015. 